\title{
EURÓPAI UNIÓ-REGIONALIZMUS-SZUVERENITÁS
}

\author{
Szerk. Beszteri Béla és Hervainé Szabó Gyöngyvér \\ (MTA Veszprémi Területi Bizottsága és Kodolányi János Főiskola, \\ Veszprém-Székesfehérvár, 1998. 379 o.)
}

\section{FINTA ISTVÁN}

Az elmúlt év során Székesfehérváron megrendezett IV, országos politológus vándorgyúlésen elhangzott előadások jelentösen hozzájárultak a regionális tudományok, illetve általában a politológia palettájának színesítéséhez. Az elöadások anyagát az „Európai Unió, Regionalizmus, Szuverenitás" címü kötetben foglalták össze. A kötet - a bevezetö referátumokon túl - hat szekció munkájába enged bepillantást. Tekintettel a tanulmányok jelentős számára, valamint az érintett témakörök széles skálájára, jelen sorok írója csupán arra vállalkozhatott, hogy néhány érdekesebb gondolat kiemelésén keresztül rávillantson egy-egy problémakör lényegére, és ezáltal késztesse az olvasót a konkrét tanulmányok, illetve a kötet egészének megismerésére.

A bevezető tanulmányok sorát Hedvig Van Staa: „Régiók Európában” címü elöadása nyitotta meg. Az elöadó - aki egyben az Európai Helyi és Regionális Önkormányzatok Gyúlésének elnöke - inkább gyakorlati oldalról közelítette meg a régiók szerepét, illetve funkcióit Európában. Az 1988-as Madridi Konvenció leglényegesebb eredményeinek vázolása után (amely pl. megkönnyítette a határokat átlépỏ helyi közösségi és regionális együttmúködést az országos, regionális településfejlesztési, környezetvédelmi, infrastrukturális szolgáltatások megszervezésében) sor kerül olyan kérdések boncolgatására, mint pl. „,mi a helyzet az EU-tagállamok föderális struktúráival?" Ezzel kapcsolatban a szerzö megállapítja, hogy jelenleg csak nagyon kevés állam rendelkezik erős, regionális tagoltsággal. Ugyanakkor „,néhány állam Európában nem akar egyáltalán régiót nemzetállami szempontjai miatt, illetve a régióknak nem akarnak kompetenciákat adni." Véleményünk szerint a regionális felosztásnak, illetve a regionális szintủ intézményrendszerek kiépítésének - mind a gazdasági élet terén, mind pedig a közigazgatás vonatkozásában - igen nagy a jelentösége a fejlődés gyorsítására vagy a gazdasági élet kihívásaira (pl. globalizáció) adott válaszok szempontjából. A szerzỏ többek között arra is felhívja a figyelmet, hogy bár Magyarország teljes jogú tag több európai szervezetben, és ô maga már két éve dolgozik a Közösségek és Régiók Kongresszusában, ennek ellenére még soha nem hallott ott magyart felszólalni. Ezért Magyarországnak jelentős pozíciókat kellene szerezni ezekben a szervezetekben.

Gombár Csaba „A szuverenitás korunkban” címü elöadása tudományos alapon, de sok gyakorlati példával színesítve közelíti meg a címben szereplö témakört. Elsőként magának a szuverenitásnak a fogalmával foglalkozik a szerző, melynek jelentését különböző történelmi korokban is definiálja. Saját megfogalmazása szerint a szuverenitás egy különleges hatalmat, az újkor elején kialakult és területileg 
elkülönült állam fơhatalmát jelenti. A szerzö meghatározásában a szuverenitás fogalma a fủggetlenség, területi integritás és az önrendelkezés attribútumával ékeskedik. Ezt követően az integráció és a globalizáció - érzelmi töltéstöl sem mentes összehasonlítására kerül sor. A szerző a globalizációt inkább negatív folyamatként fogja fel, szemben az integrációval, amely alapvetően a biztonságot és a békét célozza. A recenzens véleménye szerint a globalizáció - amely föként a gazdasági élet történéseit jellemzi - leginkább az optimális üzemméret, az optimális gazdálkodás kialakítására irányul, amely egyben a fejlödést is jelenti, annak kétségtelenül létezö negatív mellékhatásaival együtt. Épp a jogi szabályozásnak szükséges korlátok között tartania ezen mellékhatásokat, mindanélkül, hogy magának a globalizációnak valamiféle negatív jelentést tulajdonítanánk.

A szuverenitás és az integráció összevetése során a szerzỏ megállapítja, hogy bizonyos döntések integrációs szintre kerülnek, mások pedig a helyi, vagy belső régiók szintjére. A nemzetközi régiók integrativ mélységü egységesülése következtében pedig az államonként kiadagolt szuverenitás egyre inkább káprázattá válik.

„Az európai integráció és Magyarország" elnevezésủ szekcióban Beszteri Béla „Magyarország esélyei a globális világban és a régiók Európájában” címmel tartott elöadást. Megállapításai igen erös érzelmi fütöttségröl tanủskodnak és néha talán kicsit sommásnak is nevezhetők. Szerinte a globalizáció egyenlő néhány fejlett országból származó gazdasági társaság világméretü dominanciájával. Ebben a környezetben a globalitás megerősítette az Egyesült Államok vezetô szerepét a világban, amely „gátlástalanul tör céljai elérésére, világcsendőri szerepét nap mint nap mindenkivel szemben érvényesíteni kívánja." A szerző szerint az amerikai civilizáció egyetemes világtársadalmat kíván ráeröltetni a többi nagy civilizációra. Ilyen körülmények között hazánk esélyeit a rendszerváltás folyamatának eredményei bemutatásán keresztül világítja meg. Ennek alapján hazánk a konszolidáció még csak korai kezdeti szakaszában jár. Kiteljesedése az EU-tagság után várható.

Hasonló témakörben az európai integráció és Magyarország lehetőségeit latolgatja Våndor Józsefné. A szerző elsőként az integráció fogalmát tisztázza, mely szerint az nem más, mint „,válasz a világ gazdasági kihívásaira és az ahhoz történő alkalmazkodás." Egyben megállapítja, hogy az integráció több évszázados múltra tekinthet vissza, melynek oka az egyes országok közötti kölcsönös előnyök kihasználása. A szerző gazdasági szempontból a komparatív előnyök és költségek tanát tartja az integráció egyik legfontosabb tényezöjének. Jelen sorok irója bizonyos közgazdasági ismeretek birtokában csupán fel szeretné hívni a figyelmet arra, hogy a nemzeti monetáris politika, a monetáris szabályozás legalább ilyen fontos - ha nem fontosabb - a világ pénzpiaci változásaihoz történö alkalmazkodás során. A szerző a továbbiakban kiemeli, hogy a csatlakozás remélt időpontjára mintegy 7000 szabványt kellene átvenni és emellett - bár ettöl függetlenül - a csatlakozás fó gondjai között a kevésbé rugalmas, tőkeszegény cégek, valamint az évek óta vegetáló iparágak válsága, esetleges csődje szerepel. A szerző külön szól az állami szerepvállalás szükségességéröl, melynek fỏ területe eszmei, politikai síkon lelhetö fel, illetve ,az állami szerepvállalás nem nélkülözhetỏ az anyagi, szellemi erők jobb összefogása érdekében sem." 
„A regionális gondolkodás fejlödése és a regionalizmus” elnevezésü szekción belül Pap Norbert a földrajzi régió fogalom manipulálásának lehetöségeire hívta fel az érdeklődők figyelmét. Az előadás, illetve a tanulmány egyik fö értéke, hogy bemutatja, elemzi a régió fogalmát, használati körét a múltban és napjainkban. Ezt követően a nagy földrajzi gondolatrendszerek (szám szerint három) legfontosabb tételeinek felvázolására kerül sor. Az egyik ilyen elmélet a tájelmélet vagy tájföldrajz elnevezést viseli. Itt „a vizsgálódás térbeli kerete az államok határa, illetve az államokon belül közigazgatási határok voltak. A gondolatrendszerben kiemelkedő jelentöséget kaptak a természetes határok: magas hegyek, széles folyók, tenger stb." A gazdasági körzet elmélet - a második nagy gondolatrendszer - rendező elve a társadalom gazdasági aktivitása, szem előtt tartva a területi munkamegosztás sajátosságait. A harmadik elmélet - a központi hely elmélet - alapvetöen a településhálózat rendszerét, a települések közötti hierarchikus viszonyt, a települések funkcionális tartalmát stb. vizsgálja. A szerző azonban nem csupán a nagy hagyományokkal rendelkező elméleteket elemzi, hanem külön bemutatja a hazánkban jelenleg létezö térkategória rendszereket is, ezzel mintegy teljessé téve a térkapcsolatok földrajzi szempontú vizsgálatát.

Csefkó Ferenc „A területfejlesztés középszintje” címü elöadásában a megyei területfejlesztési tanácsok múködési tapasztalatai alapján fogalmazott meg a jogalkotás számára a jövőben követendố irányvonalakat, célokat. Ilyen témakörök - és megoldásra váró feladatok - pl. a területfejlesztési tanácsokat illetô fogalmi bizonytalanságok, a különbözö típusú térségek megjelenítésének kidolgozatlansága, a területfejlesztés egyes szintjei közötti feladat és hatásköri tisztázatlanságok, illetve a területfejlesztési tanácsok egész törvénykezési eljárásban való érdemi részvételének hiánya stb. A szerző külön utal hảrom fontos végrehajtási rendelet hiányára, amelyek leginkább problémát okoznak a középszintü területfejlesztés müködésében. Ezek: a területi információs rendszer hiánya, a területrendezés, illetve a területfejlesztési és rendezési koncepciók és programok tartalmi elemeit szabályozó rendeletek hiánya. A tanulmány igen tanulságos esszenciája a területfejlesztési tanácsok eddigi múködési tapasztalatainak, és egyúttal érdemei alapot teremthet a jogalkotás számára a jelentkező hiányosságok és joghézagok kitöltésére, pótlására.

"A szuverenitás, nemzetállamiság, regionalizmus" címủ szekció nyitó előadásában Navracsics Tibor egy igen érdekes kérdést, mégpedig a háromszintủ Európa jövőképét elemezgette. Ez a három szint a régiók, az egyes nemzetállamok, illetve mint legfelsőbb szint az Unió szintjéböl állna. A szerző részletesen vázolja azokat a történeti elözményeket, amelyek egyáltalán lehetővé tették, hogy a régiók szerephez juthassanak az Unión, illetve az egyes államokon belül. Ennek végső okát a szerző a gazdasági válság következményeinek elhárításában látja. A regionális érdekek képviselői elsősorban a német és belga tartományok, amelyek attól tartanak, hogy a hatáskörök átruházása - egy szinttel feljebb tolódása esetén - egyszerủ középszintủ közigazgatási, végrehajtási szintté degradálódnak. Ezért hirdették meg a háromszintú Európát, melynek egyik intézménye a Régiók Bizottsága. Ez az EU-szintủ intézmény viszont „nem lesz képes pótolni a belpolitikai nyomásgyakorlás útján történő Európa politikát”. Jelen pillanatban semmi jel sem mutat arra - írja a szerző 
Tér és Társadalom 14. évf. 2000/4. 147-159. p.

-, hogy a háromszintủ Európa a közeljövő fejleménye lenne. Ezt jelzi - többek között -, hogy a szubszidiaritás elvének kodifikálása nem a régiók által szorgalmazott formában történt. Véleményünk szerint a regionális szint növekvő gazdasági jelentőségét elöbb-utóbb szükségszerüen követnie kell a politikai (közösségi) érdekek - európai szintü - megjelenitésének is.

Szilágyi István „Regionalizmus, globalizáció, szubszidiaritás” című rövid, de annál inkább lényegre törő előadásából csupán azt emeljük ki, hogy itt nem kap negatív jelentéstartalmat a globalizáció, hanem az a gazdasági és politikai élet fejlödési eredményeként szerepel. A szerző még ennél is tovább menve kijelenti, hogy globálissá vált és válik maga a regionalizmus és a regionális integráció jelensége is.

„Az etnikai dimenzió, biztonságpolitika, Magyarország NATO csatlakozása" címü szekció elöadásának anyagából talán a biztonságpolitika az, amely jelen pillanatban is igen aktuális kérdés hazánk számára. Ezzel a témakörrel foglalkozik Matus János „A biztonságpolitika és az integráció” címủ tanulmánya. A szerző a korábbi időszakok biztonságpolitikájával kapcsolatosan megállapítja, hogy a védett értékek az egyes nemzetállamok értékei voltak. Emellett utal arra a problémára, hogy a saját biztonság erösitésére tett katonai lépéseket más államok fenyegetésként érzékelhetik és válaszlépéseikkel elindíthatják a fegyverkezési versenyt. A második világháború után, többek között ezen okokból eredöen, kialakultak a nemzetközi együttműködések. Ezt gazdasági eszközök is erősítették, hiszen a Marshall segély feltételként szabta meg az együttmüködés létrehozását. A szerző azonban külön kiemeli, hogy napjainkban a NATO döntési mechanizmusa azt jelzi, hogy az nem nemzetek feletti, hanem kormányközi szervezetként müködik. A tanulmány befejezö gondolata szerint egy ország biztonsága nagymértékben függ attól, hogy milyen pontosan érzékeli a jelenben érvényesülő trendek jövőbeni irányait.

„Az európai integráció, nyilvánosság és oktatás" elnevezésủ szekció elöadásai közül Korognai László foglalkozik az Európai Unióhoz való csatlakozásunk kommunikációs stratégiájával. A szerző szerint a kormány lakosság felé irányuló véleményformálási stratégiája három szakaszra osztható. Az elsó szakaszban a tájékoztatás a hangsúlyozott, a második szakaszban a meggyözési kampányt kell fokozni, a harmadik szakaszban pedig a mozgósítási kampányt kell megszervezni. A tanulmány értékét és életszerüségét növeli, hogy igen széles közvélemény-kutatási adatokra támaszkodik, és igen sokféle kérdés alapján alkot megalapozott véleményt. Érdekes, hogy a lakosság úgy véli, az integráció a nemzeti kultúrát és identitást nem hogy veszélybe sodorja, hanem megerősítheti, kiteljesítheti azt. A szerző azt ajánlja a döntéshozók számára, hogy külön célcsoportként vegyék figyelembe a véleményformálókat, mégpedig a pedagógusokat, az újságírókat, a médiaipar szakértőit és a tudományos szakembereket. Külön vázolja a kommunikációs stratégia eszközrendszere között az írott tájékoztatás, az elektronikus tájékoztatás és az egyes rendezvények jelentőségét.

Komanovics Adrienne „Rövid bevezetés az EU külkapcsolataiba - intézményi háttér" cimü elöadását jelen sorok írója talán a kötet egyik legértékesebb tanulmányaként tartja számon. A pozitív minösités oka abban rejlik, hogy a szerző csaknem tankönyvhöz méltó aprólékossággal mutatja be az EU intézményrendszerének fej- 
lődéstörténetét és az egyes szervek feladatainak, hatásköreinek rövid áttekintését. Az ilyen típusú - kétségtelenül leíró jellegü - tanulmány úgy véljük rendkívül fontos szerepet tölt be a kötetben. Ez a megállapítás azzal indokolható, hogy a saját véleményeket tartalmazó (esetleg tényadatokra kevéssé épülö, vagy legalábbis kevéssé megalapozott) elöadások mellett szükség van olyanokra is, amelyek képesek az esetleg hiányzó információk pótlása révén, mintegy „,képbe hozni” az olvasót.

„A helyi politika, civil társadalom" címü szekción belül Szabó Andrea tartott egy érdekes témájú elöadást „Az elit által támogatott, illetve nem támogatott tiltakozások az írott média tükrében" címmel. Valóban igaz, hogy a civil társadalom reakcióit és a hatalom cselekményeit leginkább a média képes megjeleníteni. A szerző azonban kifejezetten az írott médiára, az újságokra helyezi a hangsúlyt, felsorakoztatva érveit az elektronikus hírközléssel szemben. Ezt követöen egy egészen szük bár kétségtelenül a civil társadalmat érzékenyen érintö - témakör megvilágítására kerül sor, mégpedig a tiltakozások újságokban történö megjelenítésére. A megjelenéssel kapcsolatban két egymástól eltérő nézetet is bemutat a szerző. Az egyik álláspont szerint az ủjságok érzékenységétöl és a tiltakozás intenzitásától függ az, hogy mi is válik hírré. A másik nézet lágy és kemény információkra osztja fel a hírek alapjául szolgáló tényeket. Az előbbi az objektív, míg az utóbbi az újságtól, újságírótól függő tényekkel van kapcsolatban. Külön kitér a tanulmány a rendỏrség - mint erőszakszervezet - tiltakozással kapcsolatos szerepére. Ezzel összefüggésben az újságírók úgy vélik, hogy a rendörség fölöslegesen nem avatkozik be a megmozdulásokba. Befejezésül a szerző jelzi, hogy nem elegendő a sajtó kvantitatív vizsgálata, hanem a kvalitatív elemzésre is sort kell keríteni.

A kötet egészének értékelése nem jelent egyszerü feladatot e sorok írója számára. Kétségtelen, hogy rendkívül színes és sokrétủ témát öleltek fel az egyes szekcióüléseken elhangzott elöadások. Pozitívuma a kötetnek; hogy a tanulmányok többsége törekedett a használt fogalmak tisztázására, meghatározására. Ez a tény már önmagában alapot jelenthet egy kis politológiai szótár elkészítésének elökészítésére. A kötet negatívuma, ami azonban nem csupán erre a kötetre, hanem minden konferenciakötetre igaz lehet, az egyes előadások igényességével, kimunkáltságával, tudományos mélységével hozható összefüggésbe. Mindenesetre a kötet tartalmas olvasmányt jelent a téma iránt érdeklődők számára. 